\title{
Exfoliative Cytology in Age Estimation
}

Sankari Radhakrishnan ${ }^{1}$, Ramesh Venkatapathy ${ }^{2}$, Pennagaram D Balamurali ${ }^{3}$, Premalatha Babu ${ }^{4}$, Karthik SV Prasad ${ }^{5}$, Mohamed Thawfeek ${ }^{6}$

\section{Abstract}

Age estimation plays an important role in determining the identity of an unknown individual in case of any crime or mass disaster and is not only needed in case of dead individuals but also for living persons for record purpose.

Aims and objectives: The study was done to identify the age of an individual using the exfoliated cells of buccal mucosa by comparing the cell size. Materials and methods: Buccal smears were obtained using a wet wooden spatula by gentle scraping motion, fixed using $95 \%$ ethanol, and were stained using standard hematoxylin and the eosin staining procedure. The average cell size was measured using a stage micrometer grid. The statistical analysis of the data was done using Chi-square and Kruskal-Wallis tests.

Results: The results show the statistical significance with $p<0.001$ correlating the decrease in cell size with increasing age.

Conclusion: Age-related changes are observed in buccal smears that can be used as a tool for age estimation.

Keywords: Cell size, Exfoliative cytology, Stage micrometer.

Journal of Scientific Dentistry (2019): 10.5005/jp-journals-10083-0903

\section{BACKGROUND}

Forensic age estimation defines an expertise in forensic medicine that aims to define in the most accurate way the chronological age of a person of an unknown age involved in judicial or legal proceedings. ${ }^{1}$ In an environment where there are no clues, identification of persons poses a great difficulty. In those cases, estimation of age can help in segregating and will be the first clue to proceed. While age estimation of unidentified corpses and skeletons has a long way in forensics, age estimation of living persons is the area of research nowadays. ${ }^{2}$ The age estimation from soft tissues remains an enigma and need to be explored.

In the present scenario, an increasing demand exists for age estimation in living individuals to disentangle judicial problems. In case of minors, it is of importance at the time of adoption, child marriages, elections, and age of consent in rape. In adults, it is of importance in civil issues on pensionable age, immigrants who lack proper documentation, refugees, and asylum seekers. ${ }^{3}$ Determining the age and sex of the individual can sometimes be used to match from the missing list and further concise the population under suspicion. Age estimation in children and adolescent is possible with various methods but in adults determination of exact age is difficult. While age estimation of unidentified corpses and skeletons has a long way in forensics, age estimation of living persons is the area of research nowadays, ${ }^{2}$ of which estimation from the soft tissue is still in primary levels.

There are various methods of age estimation that are based on tooth wear, root dentin translucency, tooth cementum annulations, racemization of aspartic acid in dentin or tooth enamel, and so on. ${ }^{1}$ Radiography is one other simple and nondestructive method that can be used to assess the age of an individual based on the pulp-tooth area ratio that decreases with increase in age due to secondary dentin deposition. ${ }^{3}$

An ideal site for the manifestations of aging will be the oral cavity that continuously undergoes changes due to its rapid turnover and it is also an easily accessible site that can be opted for. Exfoliative cytology (EC) is a noninvasive technique, involving
${ }^{1}$ Private Practitioner, Mudaliarpet, Puducherry, India

${ }^{2-5}$ Department of Oral Pathology and Microbiology, Mahatma Gandhi Postgraduate Institute of Dental Sciences, Puducherry, India

${ }^{6}$ Private Practitioner, Karaikal, Puducherry, India

Corresponding Author: Sankari Radhakrishnan, Mudaliarpet, Puducherry, India, Phone: +91 9789597379, e-mail: sankari.oct2410@ gmail.com

How to cite this article: Radhakrishnan S, Venkatapathy R, Balamurali PD, Babu P, Prasad KSV, Thawfeek M. Exfoliative Cytology in Age Estimation. J Sci Den 2019;9(2):33-35.

Source of support: Nil

Conflict of interest: None

simple and pain-free collection of intact cells from different layers within the oral epithelium for microscopic examination. ${ }^{4}$

The present study uses EC for examining the exfoliated cells from the buccal mucosa to measure the cell size and to quantify the age of an individual.

\section{Aims and Objectives}

The study was done to estimate the age of an unknown individual using smear of exfoliative cells of buccal mucosa stained with hematoxylin and eosin by comparing the average cell size using a stage micrometer-microscopic grid.

\section{Materials and Methods}

The study consisted of 35 patients divided into seven groups of different age (21-25 years, 26-30 years, 31-35 years, 36-40 years, 41-45 years, 46-50 years, and above 50 years) and each group consisted of five individuals. Buccal smears were prepared from individuals of each age group. Patients with the history of systemic illness, tobacco use, or alcoholic consumption were excluded from the study. The study was explained to the participants in the vernacular language and an informed consent was obtained.

(c) The Author(s). 2019 Open Access This article is distributed under the terms of the Creative Commons Attribution 4.0 International License (https://creativecommons. org/licenses/by-nc/4.0/), which permits unrestricted use, distribution, and non-commercial reproduction in any medium, provided you give appropriate credit to the original author(s) and the source, provide a link to the Creative Commons license, and indicate if changes were made. The Creative Commons Public Domain Dedication waiver (http://creativecommons.org/publicdomain/zero/1.0/) applies to the data made available in this article, unless otherwise stated. 


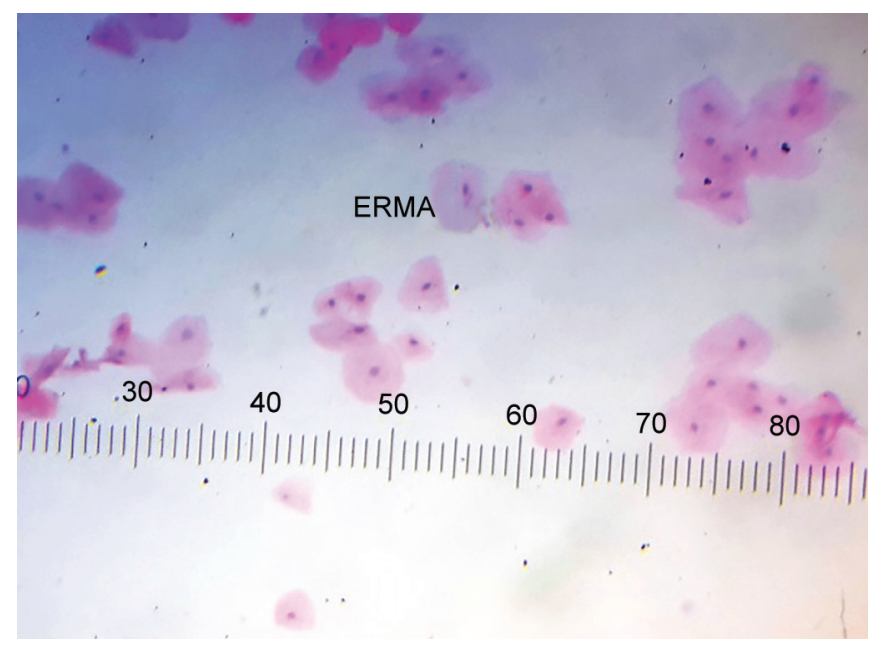

Fig. 1: Hematoxylin eosin stained buccal smear

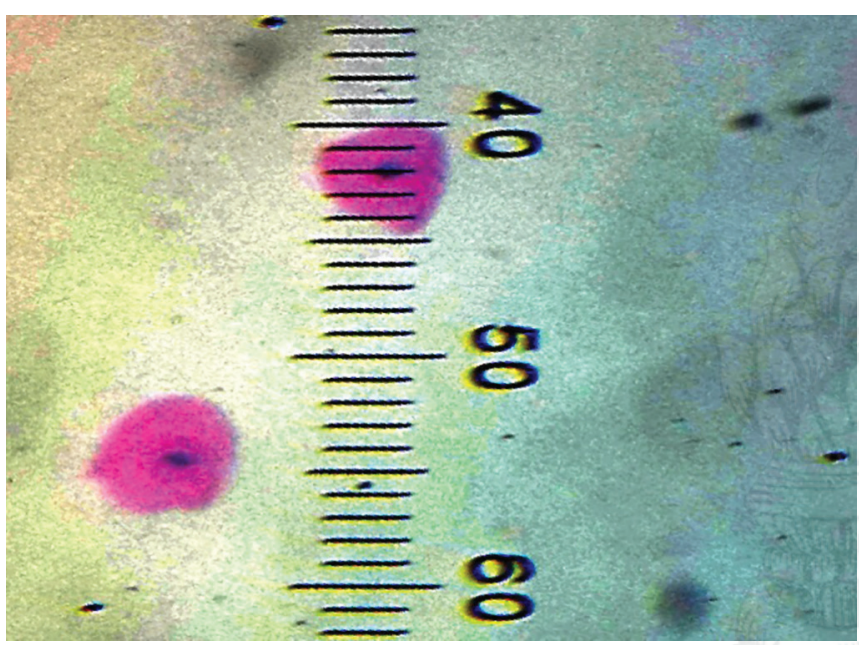

Fig. 3: A polygonal cell with centrally placed nucleus measuring $3.5 \mu \mathrm{m}$ (vertical dimension)

The oral cavity was examined and the clinically normalappearing buccal mucosa was selected to obtain the smear. A moistened wooden spatula was used with a gentle motion to scrape the buccal mucosa and smeared onto a clean glass slide.

The smear was then immediately fixed with $95 \%$ ethanol for a minimum of 15 minutes and stained using the routine hematoxylin and eosin staining technique.

The stained smears were observed in a stepwise manner, moving from left to right and then down and across, in order to avoid measuring the same cells again at $10 \times$ objective and focused on the stage micrometer scale (Fig. 1). In all the cases, the cell sizes were measured in both the horizontal and vertical axis in micrometer (Figs 2 and 3 ). Only clearly defined cells were measured, excluding the clumped or folded cells. Around 20 clearly defined cells were selected in each smear, i.e., an average of 100 cells in each age group. The average cell size values were obtained for each case and statistically analyzed using Chi-square and Kruskal-Wallis comparison tests.

\section{Results}

The cell size in group I ranged from 21.20 to $27.42 \mu \mathrm{m}^{2}$ with an overall average of $24.32{\mu \mathrm{m}^{2}}^{2}$. In group II, the cell size varied from 17.15 to $25.27 \mu \mathrm{m}^{2}$ with average of $20.56 \mu \mathrm{m}^{2}$. Group III

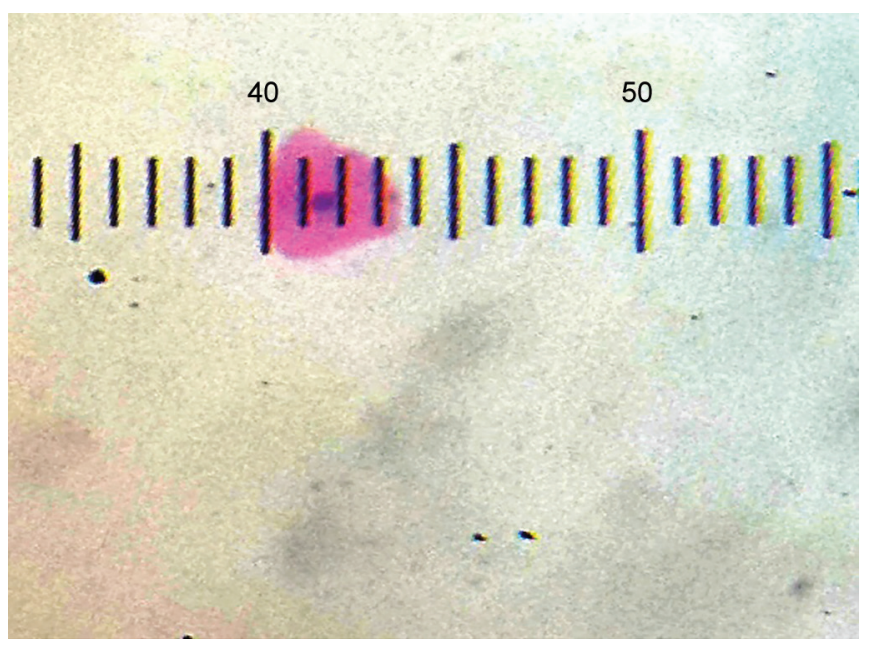

Fig. 2: A polygonal cell with centrally placed nucleus measuring $4.5 \mu \mathrm{m}$ (horizontal dimension)

showed variation in cell size from a value of $16.25-19.97 \mu^{2}$ with average cell size of $17.62 \mu \mathrm{m}^{2}$. In group IV, the cell size showed variation from a minimum value of $14.20-15.97 \mu \mathrm{m}^{2}$ and an average value of $15.30 \mu^{2}$, group $V$ showed cell size ranging from $10.50-14.70 \mu \mathrm{m}^{2}$ and average cell size of $13.28 \mu \mathrm{m}^{2}$, group VI showed cell size ranging $10.40-16.00 \mu \mathrm{m}^{2}$ with an average of $12.84{\mu \mathrm{m}^{2}}^{2}$, and group VII showed cell size ranging $7.20-12.25 \mu \mathrm{m}^{2}$ with an average of $9.07 \mu \mathrm{m}^{2}$ (Table 1). The KruskalWallis coefficient for variable cell size was found out to be $p=0.00$, $p<0.001$, which was statistically significant showing that the cell size decreases with increase in age (Table 2).

\section{Discussion}

There are various invasive and noninvasive methods for age estimation in forensic science. In the last few decades, a number of methods have been developed for age estimation among which age estimation in teenagers and adolescents claims relatively accurate estimates. ${ }^{5}$

The EC is the study of exfoliated superficial cells from the mucous membrane of oral cavity, esophagus, and genital mucosa. The normal EC of the oral epithelium was in detail studied by Paul W Montgomery in 1951 after which there are only few studies on normal buccal mucosal smears. ${ }^{6}$

The studies on oral epithelium are largely done in the pathological state. The oral exfoliative cytological technique has been used for the detection of oral premalignant, potentially malignant, or malignant lesions. ${ }^{7}$ But secrets of pathology can be explored only when the fundamental observations in normal oral mucosal cells are established. ${ }^{8,9}$ The normal oral epithelium is a stratified squamous type, and these cells, as a part of normal physiologic turnover, undergo continuous renewal by migrating from the basal layer to the surface after which they get exfoliate. ${ }^{10}$ Exfoliative cytology uses direct scrapings of the surface oral epithelium, which will remove all the layers including the basal cells. Various parameters such as nuclear and cellular size, nuclear and cellular pleomorphism, and the nuclear-cytoplasmic ratio can be analyzed using EC. ${ }^{4}$ The cellular activity, cellular organelles, and the epithelial turnover rate decrease as age advances, which could be the reason for the decrease in cell size. ${ }^{11}$

Cowpe et al. piloted a study on smears obtained from different sites of the oral cavity. Their results showed a significant variation 
Table 1: Mean and standard deviation of the cell sizes in various age groups

\begin{tabular}{|c|c|c|c|c|c|c|c|c|}
\hline Groups & $N$ & Mean $\left(\mu m^{2}\right)$ & $S D\left(\mu m^{2}\right)$ & Median $\left(\mu m^{2}\right)$ & Minimum $\left(\mu m^{2}\right)$ & $\operatorname{Maximum}\left(\mu m^{2}\right)$ & Fvalue & $p$ value \\
\hline$I(21-25)$ & 5 & 24.32 & 2.73 & 24.25 & 21.20 & 27.42 & 29.56 & $0.000^{*}$ \\
\hline II (26-30) & 5 & 20.56 & 3.12 & 20.42 & 17.15 & 25.27 & & \\
\hline III (31-35) & 5 & 17.62 & 1.73 & 16.50 & 16.25 & 19.97 & & \\
\hline IV (36-40) & 5 & 15.30 & 1.68 & 15.62 & 14.20 & 15.97 & & \\
\hline$V(41-45)$ & 5 & 13.28 & 1.66 & 14.00 & 10.50 & 14.70 & & \\
\hline VI (46-50) & 5 & 12.84 & 2.01 & 12.48 & 10.40 & 16.00 & & \\
\hline VII (>51) & 5 & 9.07 & 1.92 & 8.40 & 7.20 & 12.25 & & \\
\hline
\end{tabular}

*Significant $p<0.001$

Table 2: Significant value of 0.000 using the Kruskal-Wallis test

\begin{tabular}{|c|c|}
\hline \multicolumn{2}{|c|}{ Test statistics ${ }^{a, b}$} \\
\hline & Measurement \\
\hline Chi-square & 31.014 \\
\hline Df & 6 \\
\hline Asymp. sig. & 0.000 \\
\hline
\end{tabular}

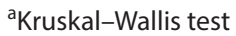

${ }^{\mathrm{b}}$ Grouping variable: group

in the nuclear diameter with age, but there was no variation in the cell diameter. ${ }^{11}$ This is in divergence to the present study where there is decrease in cell size with increasing age. Patel et al. did a cytomorphometric study in normal exfoliated gingival cells. Their results revealed an age-related significant variation in nuclear area, cytoplasmic area, and nuclear-cytoplasmic ratio, irrespective of gender, ${ }^{12}$ which is on par with the present study where the cell size showed variation with increasing age. But in our study, gender was not taken as a variable, so the cell size changes could not be related to the gender.

Shetty et al. conducted a study in the normal buccal mucosal smears, which resulted in a significant decrease in the average cell size of an individual with increasing age, which is in accordance with the present study. ${ }^{1}$

Eid et al. conducted a study on age changes in the oral mucosa and concluded with a wide range of cellular morphometric features. Their findings suggest that epithelial cells become larger with age as measured by cell area, perimeter, Feret's diameter, and breadth, which is in contrary to our study where cell size decreases as age increases. $^{13}$

Nallamala et al. conducted a study on age estimation using buccal smears and the pulp tooth ratio of the canine tooth and concluded that the age estimated using cell size from buccal mucosal smears is more accurate as compared to that of the pulptooth area ratio that can be an additional value in our study as we have used buccal smears. Also in their study there a significant decrease in the cell size with increasing age, which is the same as in our study. ${ }^{14}$

In the present study, age estimated using cell size is comparable to that of chronological age. The plot between the chronological age and cell size showed a significant correlation with only a small variant in the age group of 46-50 years. This suggests that age estimated by cell size is comparable to that of chronological age and that the cell size decreases as the age of the individual increases.

\section{Strength and Limitations}

We used the very simple exfoliative cytological procedure with routine hematoxylin and eosin stain, which is cost-effective and a standardized stain. The procedure was less technique-sensitive and also can be used as a reliable method.

Proper scraping of the mucosa to obtain the exfoliated cells and smear preparation were the two crucial factors to be considered in our study.

\section{References}

1. Shetty DC, Wadhwan V, Khanna KS, Jain A, Gupta A. Exfoliative cytology: a possible tool in age estimation in forensic odontology. J Forensic Dent Sci 2015;7(1):63-66. DOI: 10.4103/0975-1475.150321.

2. Schmeling A, Geserick G, Reisinger W, Olze A. Age estimation. Forensic Sci Int 2007;165(2-3):178-181. DOI: 10.1016/j.forsciint.2006.05.016.

3. Juneja M, Devi YB, Rakesh N, Juneja S. Age estimation using pulp/ tooth area ratio in maxillary canines-A digital image analysis. J Forensic Dent Sci 2014;6(3):160-165. DOI: 10.4103/0975-1475.137047.

4. Reddy VS, Kumar GS, Vezhavendhan N, Priya S. Cytomorphometric analysis of normal exfoliative cells from buccal mucosa in different age groups. Int J Clin Dent Sci 2011;2(3):53-56.

5. Joseph CC, Reddy BH, Cherian NM, Kannan SK, George G, Jose S. Intraoral digital radiography for adult age estimation: a reliable technique. J Indian Acad Oral Med Radiol 2013;25(4):287-290.

6. Montogomery PW. A study of exfoliative cytology in normal human oral mucosa. J Dent Res 1951;30(1):12-18. DOI: $10.1177 / 00220345510300010501$.

7. McConnell G. A Manual of Pathology, 3rd ed., Philadelphia: W. B. Saunders Company; 1915; p. 56.

8. Bibbo M. Comprehensive cytopathology, 2nd ed., Philadelphia: W. B. Saunders and Company; 1997.

9. Koss LG. The future of cytology. The Wachtel lecture for 1988. Acta Cytol 1990;34(1):1-9.

10. Anuradha A, Sivapathasundharam B. Image analysis of normal exfoliated gingival cells. Indian J Dent Res 2007;18(2):63-66. DOI: 10.4103/0970-9290.32422.

11. Cowpe JG, Longmore RB, Green MW. Quantitative exfoliative cytology of normal oral squames: an age, site and sex-related survey. J R Soc Med 1985;78(12):995-1004. DOI: 10.1177/014107688507801204.

12. Patel PV, Kumar S, Kumar V, Vidya G. Quantitative cytomorphometric analysis of exfoliated normal gingival cells. J Cytol 2011;28(2):66-72. DOI: 10.4103/0970-9371.80745.

13. Eid RA, Sawair F, Landini G, Saku T. Age and the architecture of oral mucosa. Age (Dordr) 2012;34(3):651-658. DOI: 10.1007/s11357-0119261-1.

14. Nallamala S, Venkateswara Rao Guttikonda PK, Taneeru S. Age estimation using exfoliative cytology and radiovisiography: a comparative study. J Forensic Dent Sci 2017;9(3):144-148. DOI: 10.4103/jfo.jfds_39_16. 